\title{
Climate and surface mass balance of coastal West Antarctica resolved by regional climate modelling
}

\author{
Jan T. M. LENAERTS, ${ }^{1,2}$ Stefan R. M. LIGTENBERG, ${ }^{2}$ Brooke MEDLEY, ${ }^{3}$ \\ Willem Jan VAN DE BERG, ${ }^{2}$ Hannes KONRAD, ${ }^{4}$ Julien P. NICOLAS, ${ }^{5}$ \\ J. Melchior VAN WESSEM, ${ }^{2}$ Luke D. TRUSEL, ${ }^{6}$ Robert MULVANEY, ${ }^{7}$ \\ Rebecca J. TUCKWELL, ${ }^{7}$ Anna E. HOGG, ${ }^{4}$ Elizabeth R. THOMAS ${ }^{7}$ \\ ${ }^{1}$ Department of Atmospheric and Oceanic Sciences, University of Colorado, \\ Boulder, CO, USA \\ Email: Jan.Lenaerts@colorado.edu \\ ${ }^{2}$ Institute for Marine and Atmospheric Research Utrecht, Utrecht University, Utrecht, The Netherlands \\ ${ }^{3}$ Cryospheric Sciences Laboratory, NASA Goddard Space Flight Center, Greenbelt, MD, USA \\ ${ }^{4}$ Centre for Polar Observation and Modelling, University of Leeds, Leeds, UK \\ ${ }^{5}$ Byrd Polar and Climate Research Center, Ohio State University, Columbus, OH, USA \\ ${ }^{6}$ Department of Geology, Rowan University, Glassboro, NJ, USA \\ ${ }^{7}$ British Antarctic Survey, Cambridge, UK
}

\begin{abstract}
West Antarctic climate and surface mass balance (SMB) records are sparse. To fill this gap, regional atmospheric climate modelling is useful, providing that such models are employed at sufficiently high horizontal resolution and coupled with a snow model. Here we present the results of a high-resolution $(5.5 \mathrm{~km})$ regional atmospheric climate model (RACMO2) simulation of coastal West Antarctica for the period 1979-2015. We evaluate the results with available in situ weather observations, remotesensing estimates of surface melt, and SMB estimates derived from radar and firn cores. Moreover, results are compared with those from a lower-resolution version, to assess the added value of the resolution. The high-resolution model resolves small-scale climate variability invoked by topography, such as the relatively warm conditions over ice-shelf grounding zones, and local wind speed accelerations. Surface melt and SMB are well reproduced by RACMO2. This dataset will prove useful for picking ice core locations, converting elevation changes to mass changes, for driving ocean, ice-sheet and coupled models, and for attributing changes in the West Antarctic Ice Sheet and shelves to changes in atmospheric forcing.
\end{abstract}

KEYWORDS: accumulation, Antarctic glaciology, ice/atmosphere interactions, snow/ice surface processes, surface mass budget

\section{INTRODUCTION}

The West Antarctic Ice Sheet (WAIS) comprises an ice volume equivalent to $\sim 4.3 \mathrm{~m}$ of sea level (Fretwell and others, 2013). Most of the ice on the WAIS is grounded well below sea level on bedrock that slopes down from the coast to the interior ice sheet, designating it as a 'marinebased ice sheet' (Thomas, 1979). Fast-flowing ice streams transport accumulated snow and firn from the high interior to the coast, supplying mass to floating ice shelves. In an equilibrium state, these ice shelves lose an equivalent amount of mass either by iceberg calving at their front, or by basal melting at the bottom where the shelves are in contact with the ocean water. Oceanic warming is supplied by circumpolar deep water (CDW) originating from the continental shelf and is transported to the ice-shelf base through deep submarine bedrock troughs (Jacobs and others, 2012).

The Amundsen Sea Embayment (ASE, Turner and others, 2017, Fig. 1) constitutes an epicentre of these strong iceocean interactions and recent changes therein. Owing to enhanced supply of CDW to the ASE ice shelves, these have been progressively thinning throughout the past two and half decades (Pritchard and others, 2012; Paolo and others, 2015). The diminishing support from their ice shelves led to considerable speed-up of the ASE glaciers (Mouginot and others, 2014), grounding-line retreat (Park and others, 2013; Scheuchl and others, 2016), and upstream propagation of thinning into the interior (Konrad and others, 2017), manifesting in a by $77 \%$ increased solid ice discharge from this area (Mouginot and others, 2014). Numerical simulations of future glacier dynamics drive the speculation that this observed imbalance will be followed by rapid, widespread and potentially irreversible deglaciation of the ASE region (Joughin and others, 2014).

The intense ice/ocean interactions are strongly regulated by atmospheric variability, which is larger in the ASE than anywhere on the Earth (Connolley, 1997). The atmospheric conditions over the ASE are primarily determined by the strength and location of the Amundsen Sea Low (ASL, Raphael and others, 2015), the climatological low-pressure centre located north of the ASE. In turn, the atmospheric dynamics are in part driven by tropical climate variability (Bromwich and others, 2004; Bertler and others, 2006; Ding and others, 2011; Steig and others, 2012; Clem and Renwick, 2015) as well as atmospheric pressure differences between low and high latitudes of the Southern Hemisphere (i.e. the Southern Annual Mode SAM, 

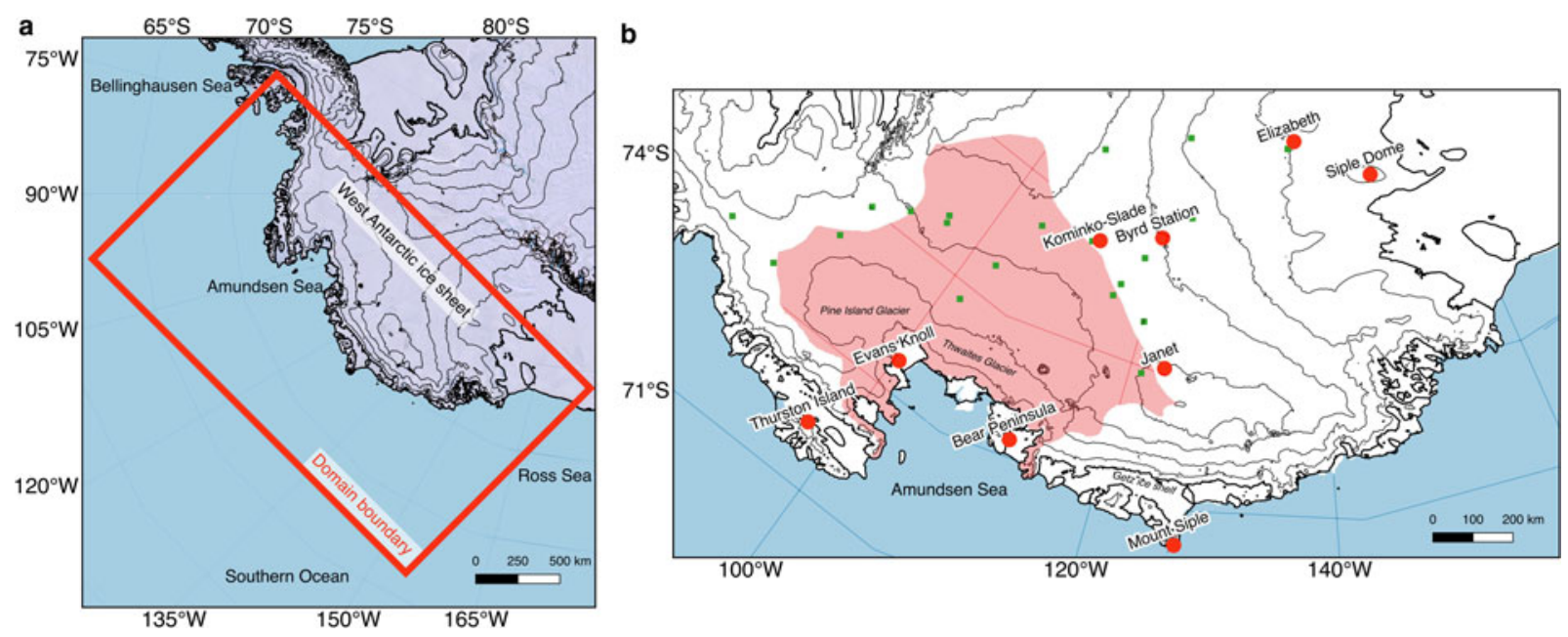

Fig. 1. Overview of the model domain. (a) Location of the domain on the Antarctic ice sheet and neighbouring ocean areas. The red square shows the domain boundary. (b) Zoom on inner model domain with the locations of the automatic weather stations (AWSs) shown with red dots. The red shading shows the area for which the mass balance is calculated (see Fig. 11). The green squares show the locations of the PAGES $2 \mathrm{k}$ firn cores (see Fig. 9). In both maps (and in all maps that follow), the thick black line is the ice-sheet grounding line (from Depoorter and others, 2013) and the thin black lines show elevation (Bamber and others, 2009) at $500 \mathrm{~m}$ contour intervals.

Scambos and others, 2017). The position and strength of the ASL not only determine the meridional flow that control CDW delivery onto the continental shelf (Thoma and others, 2008), but also drives atmospheric heat and moisture supply to the ice sheet (Nicolas and Bromwich, 2011; Fyke and others, 2017). Coastal ASE receives some of the highest snowfall amounts of Antarctica (Lenaerts and others, 2012b), owing to frequent landfall of deep moisture plumes originating from the tropics, so-called atmospheric rivers (Gorodetskaya and others, 2014).

These atmospheric rivers interact with the complex topography, generating steep precipitation gradients (Nicolas and Bromwich, 2011). Behind these coastal ridges, moisture quickly dissipates, leaving the interior ice sheet much drier. In order to resolve these gradients, atmospheric climate models should resolve features smaller than the typical length scale of topography, i.e. $10-100 \mathrm{~km}$, which is smaller than the resolution currently employed in global climate models. Even though some models simulate largescale atmospheric patterns correctly, their resulting precipitation patterns are smoothed out because topography is poorly resolved (Medley and others, 2013). As a result, most climate models overestimate interior precipitation over Antarctica (Palerme and others, 2016). To overcome these deficiencies, regional atmospheric climate models are useful tools (Lenaerts and others, 2012b; Van Wessem and others, 2014b). They dynamically downscale the large-scale atmospheric structure to horizontal resolutions that are more consistent with the ice sheet topography, and their resulting climate gradients are better suited to drive ice sheet and ocean models.

Additionally, an important mechanism to drive ice-shelf hydrofracturing and ice cliff instability is ice-shelf surface melting (DeConto and Pollard, 2016). The ratio between surface melt and snowfall is an indicator of ice-shelf firn 'health' (Kuipers Munneke and others, 2014): as surface melt increases under constant snowfall, firn saturates with water and warms, decreasing pore space and enhancing risk for meltwater ponding, and surface-based water can percolate all the way to the bottom of the ice shelf. Potentially, this results in catastrophic ice-shelf breakup, which was evidenced by the Larsen B breakup in early 2002. Although mapping surface melt extent is possible with remote sensing (e.g. Tedesco and Monaghan, 2009), deriving surface melt volume is much more challenging (Trusel and others, 2013), as it requires in situ melt observations that are not always representative for a larger area. Moreover, surface melt rates are highly spatially heterogeneous over ice shelves and the ice sheet. Melt is typically concentrated in a narrow band close to the ice-shelf grounding line (Luckman and others, 2014; Hubbard and others, 2016), where warm winds erode the firn and create a local microclimate (Lenaerts and others, 2017b). Melt events, even those that are marginal and short-lived, can substantially alter the energy balance during the rest of the melt season (Trusel and others, 2013). Regional climate models, which incorporate the necessary surface processes, provided they are employed at fine resolution, have been shown to successfully represent these features (Lenaerts and others, 2012a, 2014a; Van Wessem and others, 2016; Lenaerts and others, 2017a).

To resolve these important climate and surface mass balance $(\mathrm{SMB})$ processes over the ASE, we employ the regional atmospheric climate model RACMO2 at unprecedentedly high horizontal resolution $(5.5 \mathrm{~km})$ over this region for the period 1979-2015. Here we present the results of this simulation, evaluate the results using novel observational data, and discuss the added value of the high horizontal resolution. Section 'Methods and data' presents the numerical setup and observational data, section 'Results' discusses the results, and section 'Discussion and conclusions' gives conclusions and discussion.

\section{METHODS AND DATA}

\section{Regional climate model}

In this study, we use the Regional Atmospheric Climate MOdel, version 2.3p2 (Noël and others (2017), RACMO2 hereafter). RACMO2 combines the representation of atmospheric dynamics of the High Resolution Limited Area 
Table 1. Overview of weather stations used in the comparison with RACMO2

\begin{tabular}{|c|c|c|c|c|c|c|c|c|}
\hline \multirow[t]{2}{*}{ Station name } & \multirow[t]{2}{*}{$\begin{array}{l}\text { Latitude } \\
\left({ }^{\circ} \mathrm{S}\right)\end{array}$} & \multirow[t]{2}{*}{$\begin{array}{l}\text { Longitude } \\
\left({ }^{\circ} \mathrm{W}\right)\end{array}$} & \multirow[t]{2}{*}{$\begin{array}{l}\text { Elevation } \\
\mathrm{m}\end{array}$} & \multicolumn{2}{|c|}{$\begin{array}{c}\text { Elevation bias } \\
\text { m }\end{array}$} & \multirow[t]{2}{*}{ Time period } & \multirow[t]{2}{*}{ Months temperature } & \multirow[t]{2}{*}{ Months wind speed } \\
\hline & & & & $\mathrm{R} 27$ & R5.5 & & & \\
\hline Bear Peninsula & 74.55 & 111.89 & 312 & -46 & -87 & Feb 2011-Dec 2015 & $59 / 59$ & $57 / 59$ \\
\hline Byrd Station & 80.01 & 119.44 & 1539 & -2 & 4 & Feb 1980-Dec 2015 & $306 / 431$ & $191 / 431$ \\
\hline Elizabeth & 82.61 & 137.08 & 519 & -18 & 12 & Mar 1996-Dec 2015 & $121 / 238$ & $75 / 238$ \\
\hline Janet & 77.17 & 123.39 & 2085 & 18 & 5 & Jan 2011-Dec 2015 & $51 / 60$ & $35 / 60$ \\
\hline Kominko-Slade & 79.47 & 112.11 & 1801 & 12 & 4 & Feb 2009-Dec 2015 & $83 / 83$ & $38 / 83$ \\
\hline Mount Siple & 73.32 & 127.09 & 230 & -226 & -64 & Mar 1992-Feb 2012 & $140 / 240$ & $0 / 240$ \\
\hline Siple Dome & 81.65 & 148.99 & 667 & -37 & -4 & Jan 2012-Dec 2015 & $48 / 48$ & $30 / 48$ \\
\hline Thurston Island & 72.53 & 97.55 & 145 & 251 & -42 & Feb 2011-Dec 2015 & $59 / 59$ & $26 / 59$ \\
\hline
\end{tabular}

The two rightmost columns show the number of months with data availability and the total number of months (available/total).

Model (HIRLAM, version 5.0.6 Unden and others, 2002), while the description of the physical processes is adopted from the European Centre for Medium-range Weather Forecasts (ECMWF) Integrated Forecast System (IFS) (ECMWF-IFS, 2008). It has been adapted for use over the large ice sheets of Greenland and Antarctica, including a multi-layer snow model to calculate melt processes (Ettema and others, 2010), surface albedo (Kuipers Munneke and others, 2011), and blowing snow (Lenaerts and Van Den Broeke, 2012). RACMO2 topography is based on the Bamber and others (2009) digital elevation model, derived from a combination of satellite radar and laser data.

Previous studies using RACMO2 found that the model underestimates the amount of clouds and the resulting snowfall in the ice-sheet interior of both Greenland (Noël and others, 2015) and Antarctica (Van Wessem and others, 2014a). Therefore, in this updated version, the critical cloud content for efficient precipitation generation has been increased by a factor 2 and 5 for liquid/mixed and ice clouds, respectively. As a result, cloud content can now be advected further inland, likely further decreasing biases in the AIS interior (Van Wessem and others, 2014a). Furthermore, the linear saltation snow load parameter (Eqn (24), Déry and Yau, 1999) used in the RACMO2 drifting snow is halved, i.e. from 0.385 to 0.190 (Lenaerts and others, 2014b), effectively halving the horizontal drifting snow transport and drifting snow sublimation flux, without changing the length nor frequency of the drifting snow events.

In this setup, the climate model is employed for a spatial domain encompassing a large part of the WAIS coastal region (Fig. 1), stretching from the Wilkins ice shelf in the east (at $\sim 75^{\circ} \mathrm{W}$ ) to the central Ross ice shelf in the west $\left(\sim 175^{\circ} \mathrm{W}\right)$. A large part of the domain contains ocean/seaice covered points, to ensure that the northern edge of the domain, which receives a large part of the large-scale atmospheric fluxes transported into the domain, is located sufficiently far away $(>1000 \mathrm{~km})$ from the ice-sheet coast. Moreover, this allows using these atmospheric data as forcing for regional ASE ocean models. RACMO2 is forced at these edges by vertical atmospheric profiles of temperature, humidity and winds, as well as sea surface temperature and sea-ice cover, from ERA-Interim atmospheric reanalysis (Dee and others, 2011), which is available from January 1979 onwards. The choice of ERA-Interim forcing is justified by its realistic climate over the high-latitude Southern Hemisphere, outperforming other reanalysis products in its representation of near-surface climate over Antarctica as a whole (Bracegirdle and Marshall, 2012) and the Amundsen Sea region (Jones and others, 2016). The forcing from ERAInterim at the ocean surface implies that our modelling approach does not simulate ocean dynamics and their impact on ice-shelf dynamics. In RACMO2, the ice shelves are assumed to be grounded ice and are not allowed to change thickness or shape. RACMO2 is employed at a horizontal resolution of $5.5 \mathrm{~km}$, resulting in a domain of 456 longitudinal and 361 latitudinal grid cells. Here we present the RACMO2 results for the time period January 1979December 2015. We compare the RACMO2 data with new observations of near-surface climate, surface melting, and $\mathrm{SMB}$, and with RACMO2 output generated at a lower horizontal resolution $(27 \mathrm{~km}$, van Wessem and others, 2017). The latter is produced from a RACMO2 simulation performed for the full Antarctic domain, with exactly the same physics as the high-resolution simulation. This allows us to assess the added value of the higher resolution in representing the coastal WAIS climate and SMB.

\section{Observations}

\section{Weather stations}

To evaluate the performance of the high-resolution RACMO2 simulation, the simulated climate was compared to 2-m temperature (T2m) and 10-m wind speed (FF10m) observations from nine AWSs located in West Antarctica (Fig. 1, Table 1). AWS data at three-hourly intervals were obtained from Antarctic Meteorological Research Center (AMRC) and AWS program (https://amrc.ssec.wisc.edu/).

The nine stations are relatively evenly distributed over the domain (Fig. 1b) and can be classified into coastal stations (from east to west: Thurston Isl., Evans Knoll, Bear Pen. and Mt. Siple) and interior stations. Of these latter stations, three are located close to the West Antarctic ice divide (Byrd Station, Kominko-Slade and Janet) and two are on the south side of the divide, near the Siple Coast (Elizabeth, Siple Dome). For all locations, the grid points closest to the weather station were used for the comparison (Table 1), with a single exception: for Bear Peninsula, a R5.5 neighbouring grid point was chosen to better mimic the conditions of the location of the AWS, situated on a rock outcrop on the edge of the peninsula and situated $\sim 200 \mathrm{~m}$ above the ice shelf. For the coastal stations, the elevation difference between the AWS location and RACMO grid points is often 
significant (50-100 m, Table 1), since the AWS is usually situated on bedrock outcrops or nunataks in rough topographical terrain.

Almost all stations have data available for the last 5 years (2011-15), with only three stations having records that extend back before 2008: Byrd Station from 1980 onwards, Elizabeth from 1996 onwards and Mount Siple from 1992 onwards (Table 1). Monthly averages are calculated from the 3-hourly AWS data and a monthly average was used in the evaluation if data were available for at least $95 \%$ of time during that month. For the evaluation of 3-hourly data, all available AWS data were used.

\section{Radar and firn cores}

SMB can be observed using a combination of radar (airborne or ground-based) and firn cores. The reconstruction relies on internal reflections in firn and ice caused by density variations due to surface conditions at the time of deposition, which can therefore be assumed to be of isochronous origin (Vaughan and others, 1999). The respective signal travel times measured by the radar can be converted into water equivalent depth using an empirical relation between firn density and the dielectric constant (Kovacs and others, 1995), with a regionally averaged firn density profile based on density measurements at distinct firn core locations.

Here we use two datasets that combine radar and firn cores. Firstly, the airborne shallow radar suite developed by the Center for Remote Sensing of Ice Sheets (CReSIS) and flown on NASA's Operation IceBridge (OIB) mission provides an unparalleled peek into the subsurface firn stratigraphy. We specifically use the snow radar, which is an ultra-wideband microwave radar system that operated over the frequency range of $4-6 \mathrm{GHz}$ in 2009 and 2-6.5 GHz subsequently (Leuschen, 2014). This frequency-modulated continuous-wave (FM-CW) radar system images the stratigraphy in the upper $20-30 \mathrm{~m}$ of the ice sheet with fine vertical resolution (a few centimetres) and an along-track spacing of a few tens of metres (Medley and others, 2013; Panzer and others, 2013). Snow radar data have been collected in Antarctica annually since 2009 (with the exception of 2015), covering much of coastal West Antarctica and its peripheral ice shelves. The use of OIB airborne radar allows us to evaluate the spatial pattern of SMB over the complex topography surrounding the Getz Ice Shelf, which includes several prominent ice domes. We use data collected on 5 November 2010, which surveys several of these ice domes. Although Medley and others (2013) mapped several annual horizons for evaluation of temporal variations in SMB, because we are mainly interested in evaluating the spatial patterns in R5.5, we map a single, strong horizon in the radar data that corresponds to 3 years of accumulation (2008-10). After picking the surface return, we applied an automated picker to find several strong peaks in return power below the surface for each trace, but recorded only the third peak (i.e. 3 years of accumulation). Erroneous picks were filtered out, and visual inspection of the horizon pick confirmed we were consistently picking the same horizon. We use a method described in Medley and others (2015), which allows for spatial variations in the firn density profile in both radar-depth estimation as well as conversion to water equivalence. The method iteratively solves for a depth-density profile at each measurement that is consistent with the radar-derived accumulation rate as well as long-term modeled 2-m air temperature from MERRA-
2 and an initial density of $350 \mathrm{~kg} \mathrm{~m}^{-3}$. Thus, we create 3 -year mean annual estimates of 2008-10 SMB. To improve the comparison with RACMO2, we use OIB Airborne Topographic Mapper resampled and smoothed nadir elevation measurements (ILATM2; Krabill, 2010). We additionally use 19852009 mean annual radar-derived accumulation presented by Medley and others (2014) to evaluate RACMO2 over Pine Island and Thwaites catchments. The 20000 measurements are spaced at $\sim 500 \mathrm{~m}$ increments over resulting in $10000 \mathrm{~km}$ of along-track data covering an area of $300 \times 103 \mathrm{~m}^{2}$.

Secondly, we use new firn core and ground-penetrating radar (GPR) records collected within the scope of NERC's Ice Sheet Stability Programme iSTAR. These were acquired on Pine Island Glacier for reconstructing SMB along a 900-km long traverse covering the glacier's main tributaries. The radar acquisition was carried out in the 2013/14 field season using a commercially available pulseEKKO PRO device operating at $100 \mathrm{MHz}$ with transmitter and receiver antennae in common-offset mode. The radar data were routinely processed by a static correction, bandpass filtering, background removal, and gain correction. A distinct reflector was picked by eye along most of the traverse. Where the radar data were interrupted along the traverse, the age-depth distribution of the firn cores (see below) served as a guidance to identify the corresponding reflector. Firn cores of $\sim 50 \mathrm{~m}$ depth each were drilled in the 2014/15 field season at ten main landmarks of the traverse. Their chronologies were established by analysing annual cycles in hydrogen peroxide (Sigg and Neftel, 1988), by which the picked reflector was dated to stem from 1986. The SMB was then computed by dividing water equivalent depth of the reflector by its age. The uncertainty of the SMB incorporates the wavelength of the radar wavelet (Navarro and Eisen, 2009), the uncertainty in speed of light as reflected in the variability of density in the ensemble of firn cores, the variance of the ages at the core locations, and an additional age uncertainty of 1 year to accommodate the delay between radar and firn core acquisition.

In complement to these two datasets, we use a recently compiled dataset of firn core SMB for RACMO2 model evaluation. Coordinated by the Past Global Changes (PAGES) Antarctica $2 \mathrm{k}$ working group, all available firn core SMB records on Antarctica were collected and thoroughly quality checked (Thomas and others, 2017). Here we use the 21 cores for the period 1979-2012 (or the temporal subset of this period covered by the firn core) spread around the R5.5 domain (Fig. 1b, Thomas and others, 2017). All of these cores were drilled at elevations between 1000 and $2000 \mathrm{~m}$ above sea level, with a mean SMB varying from 100 to 500 mm w.e. $a^{-1}$

\section{Remote sensing of surface melt}

RACMO2 surface melt volume is compared to the 2000-09 mean surface melt volume derived from QuikScat scatterometery available at $\sim 5 \mathrm{~km}$ horizontal resolution (Trusel and others, 2012). Because this dataset encompasses only 10 years, and interannual variability in surface melt is substantial (Kuipers Munneke and others, 2012), temporal variations of surface melt in RACMO2 are compared with a new surface melt occurrence dataset spanning the entire simulation period 1979-2015 (Nicolas and others, 2017). This dataset uses brightness temperatures (Tbs) from a series of spaceborne sensors: The Scanning Microwave Multichannel Radiometer (SMMR) onboard the Nimbus-7 satellite (1978-87); the 
Special Sensor Microwave/Imager (SSM/I) onboard successive satellites (F-8, F-11 and F-13) from the Defense Meteorological Satellite Program (DMSP; 1987-2009); and the Special Sensor Microwave Imager Sounder (SSMIS) onboard DMSP F-17 satellite (2006-present). The data are provided by the National Snow and Ice Data Center on an equal-area scalable Earth grid with a nominal resolution of $25 \mathrm{~km}$ (Armstrong and others, 1994; Knowles and others, 2000). We use horizontally polarized Tb data in the K-band $(18 \mathrm{GHz}$ for SMMR, $19 \mathrm{GHz}$ for SSM/I-SSMIS), previously used for melt detection over ice sheets (e.g. Liu and others, 2006; Picard and others, 2007; Tedesco, 2009). These observations are available twice-daily (from the ascending and descending satellite overpasses). More details on the melt detection algorithm are described by Nicolas and others (2017). For a given grid cell and a given day, we determine that melt was occurring as soon as one of the two daily Tb observations exceeded a threshold value (Tbmelt) defined as Tbmelt $=$ Tbref $+\delta T$, where $\delta T=$ $30 \mathrm{~K}$ and Tbref is a reference temperature. Tbref is calculated as the 12-month average from 1 April to 31 March after filtering out all melt days as in Torinesi and others (2003). To compare model and observations, we use the melting index (Zwally and Fiegles, 1994), which is defined as the annual accumulated product (1 April-31 March) of daily melt occurrence (units in $\mathrm{km}^{2} \times$ days). For the model, we use a predefined melt threshold of $3 \mathrm{~mm} /$ day, to optimize the correspondence with the observations.

\section{RESULTS}

\section{Near-surface temperature and wind}

Simulated near-surface temperature and wind speed fields display a high level of spatial detail (Fig. 2). The annual mean temperature is highest $(>260 \mathrm{~K})$ over the oceans adjacent to the ice sheet. Generally, near-surface temperatures gradually decrease from the lower to the high-elevation areas, but the high-resolution model displays some interesting regional climate phenomena. For instance, the temperatures are higher in the grounding zone $(0-50 \mathrm{~km}$ seaward from the grounding line), along the high-sloping areas inward of the ice shelves, and on the sides of the small ice domes and ice rises, than on the ice shelves themselves.
This is explained by the enhanced turbulent mixing in these areas (King, 1998; Lenaerts and others, 2017b). The ice shelves themselves are typically cold, especially the Ross Ice Shelf, where surface-based temperature inversions are known to be well developed and associated with lowlevel jets (Seefeldt and Cassano, 2008). The general wind field is largely dominated by katabatic flow originating from the interior ice sheet (Fig. 2). The strongest mean winds are found over confluent topography such as the interior Pine Island Glacier $\left(76^{\circ} \mathrm{S}, 95^{\circ} \mathrm{W}\right)$. Additional, smallerscale wind patterns are discernible over some coastal ice domes, which act to accelerate winds. One of the clearest examples is Martin Peninsula $\left(74^{\circ} \mathrm{S}, 115^{\circ} \mathrm{W}, \mathrm{MP}\right.$ in Fig. 2), where mean wind speeds vary from $5 \mathrm{~m} \mathrm{~s}^{-1}$ on the lee side to $9 \mathrm{~m} \mathrm{~s}^{-1}$ on its north side (not shown). This local flow acceleration due to larger-scale topography shows remarkable similarities to, but is much more poorly documented than, the southern Greenland 'tip jet' (Doyle and Shapiro, 1999; Moore and Renfrew, 2005).

The evaluation of the simulated T2m and FF10m for both RACMO2 simulations are shown in Figures 3, 4, and the statistics per station are listed in Tables A1, A2 (in the appendix), respectively. For the monthly average near-surface temperature of all stations (Fig. 3a), little difference can be discerned between the high- and low-resolution RACMO2 results; mostly, simulated temperatures are within $2 \mathrm{~K}$ of the observed temperatures, although some outliers are found with a maximum absolute bias of $5 \mathrm{~K}$. Also, the points are centered on the 1:1-line, indicating that there is no clear bias in either simulation. The variance and the RMSE show that R5.5 (0.97 and 3.83) slightly outperforms R27 (0.95 and 4.78), with the same being true for almost all individual stations (Table A1). The 3-hourly data for all stations are not plotted in Figure 3a due to the high number of measurements, but they show the same pattern. The difference between the R5.5 and R27 is slightly larger for the 3-hourly than for the monthly data, with R5.5 again scoring better.

Figures $3 b$, c show the same comparison only for two individual stations and including the 3-hourly observations. For the inland station (Byrd station, Fig. 3c) the pattern is similar to the one for all stations combined: no bias from the 1:1-line and no visual differences between R5.5 and R27, while the statistics slightly favour R5.5 over R27

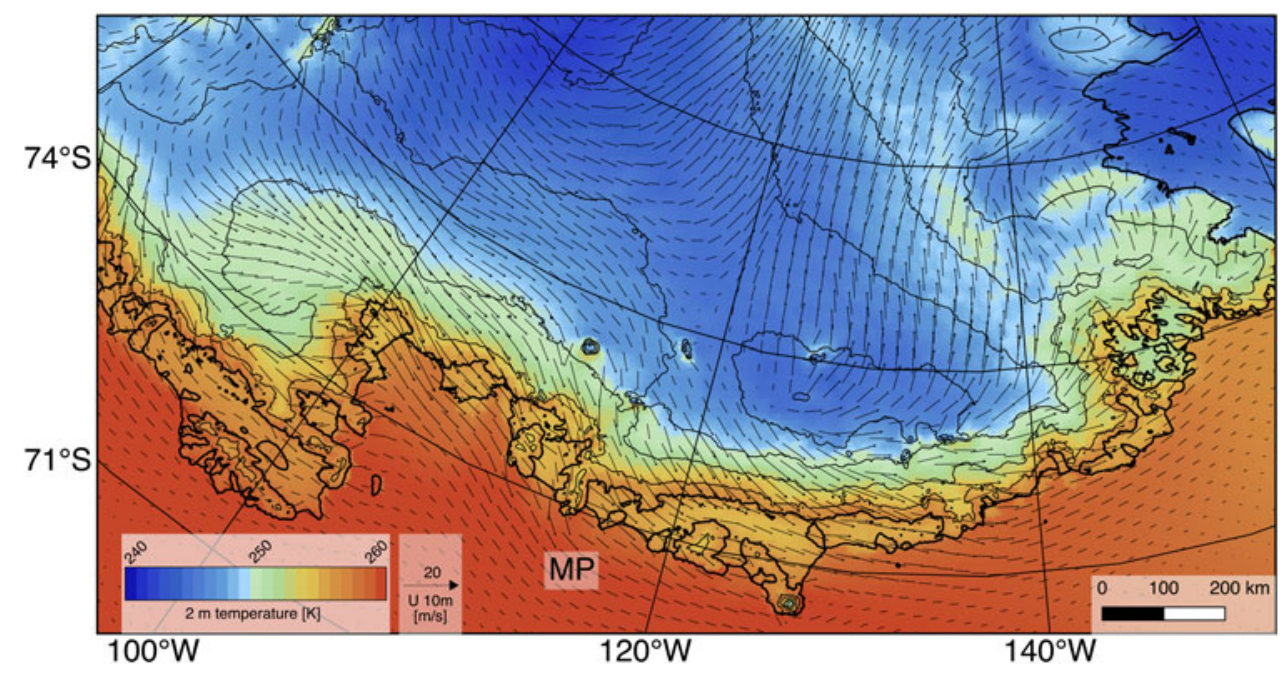

Fig. 2. Annual mean (1979-2015) simulated (R5.5) near-surface temperature (at $2 \mathrm{~m}$, colours) and wind vectors (at $10 \mathrm{~m}$, arrows). The location of Martin Peninsula is marked by MP. 

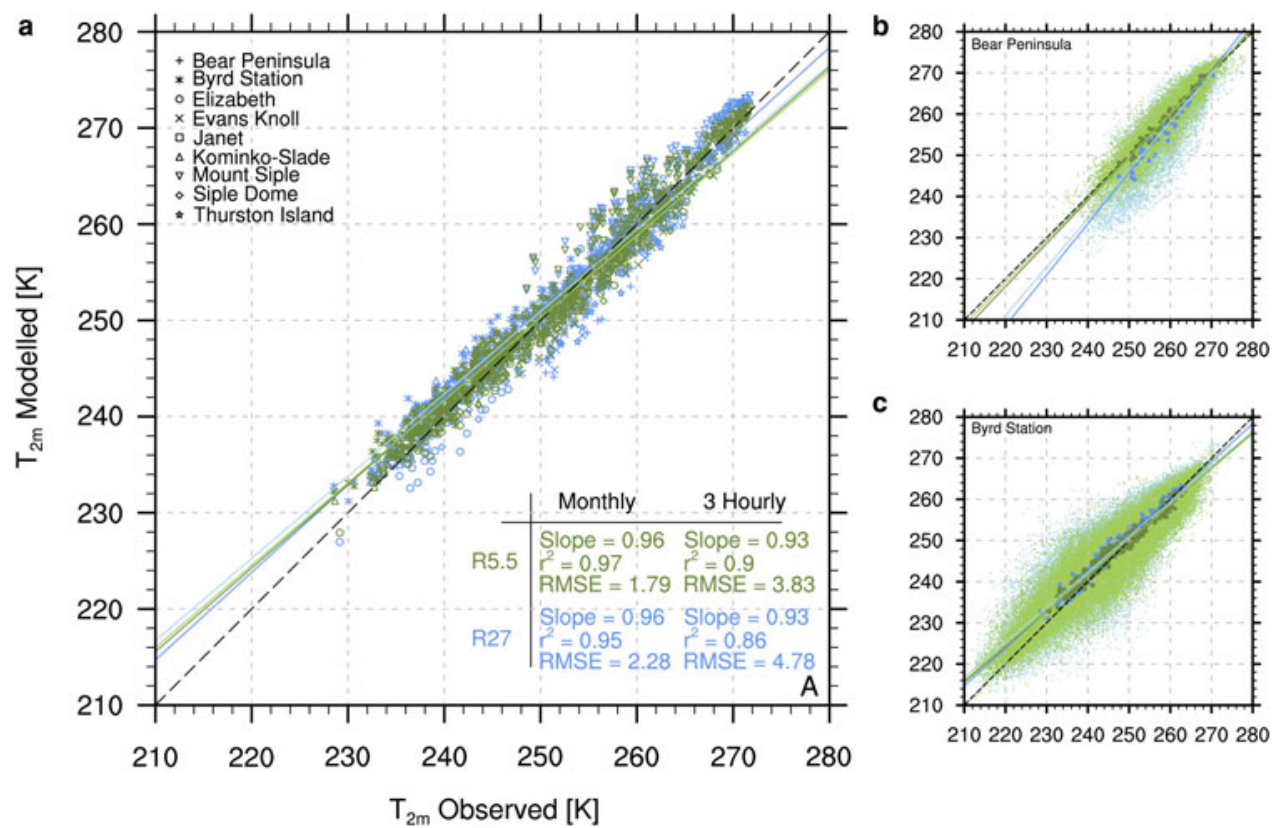

Fig. 3. Scatter plots of observed (AWS) vs. simulated (R5.5 in green, R27 in blue) near-surface temperature. (a) All stations; (b) Bear Peninsula; (c) Byrd Station. In panels (b) and (c), the opaque markers show the 3-hourly data, and the clear markers show the monthly mean data. The statistics are given for both monthly and 3-hourly comparisons in each plot. The coloured lines show the 1:1 line (black) and the best linear fit for R5.5 (green) and R27 (blue).

(Table A1). For the coastal station (Bear Peninsula, Fig. 3b) the R27 simulation shows a clear negative temperature bias compared with the observations, which is probably caused by the lack of topographical detail in R27. In the low-resolution simulation, the topography is smoothened and the grid point is located on the flat Dotson Ice Shelf where the strong near-surface inversion causes very cold winter conditions. In reality, however, the AWS is situated on a rock outcrop $\sim 200 \mathrm{~m}$ above the ice shelf where it is less impacted by these cold winter inversion conditions. In R5.5, the topographical difference between the flat ice shelf and surrounding islands is much better captured leading to a better representation of the near-surface temperature.

For the 10-m wind speed comparison roughly the same conclusion can be drawn from the 2-m temperature comparison: on average, R5.5 slightly outperforms R27 on both the monthly and 3-hourly data (Fig. 4a and Table A2). However, the agreement between observations and modelled wind speed is significantly worse than for temperature. For Bear Peninsula (see also Fig. 3b) and Thurston Island, the
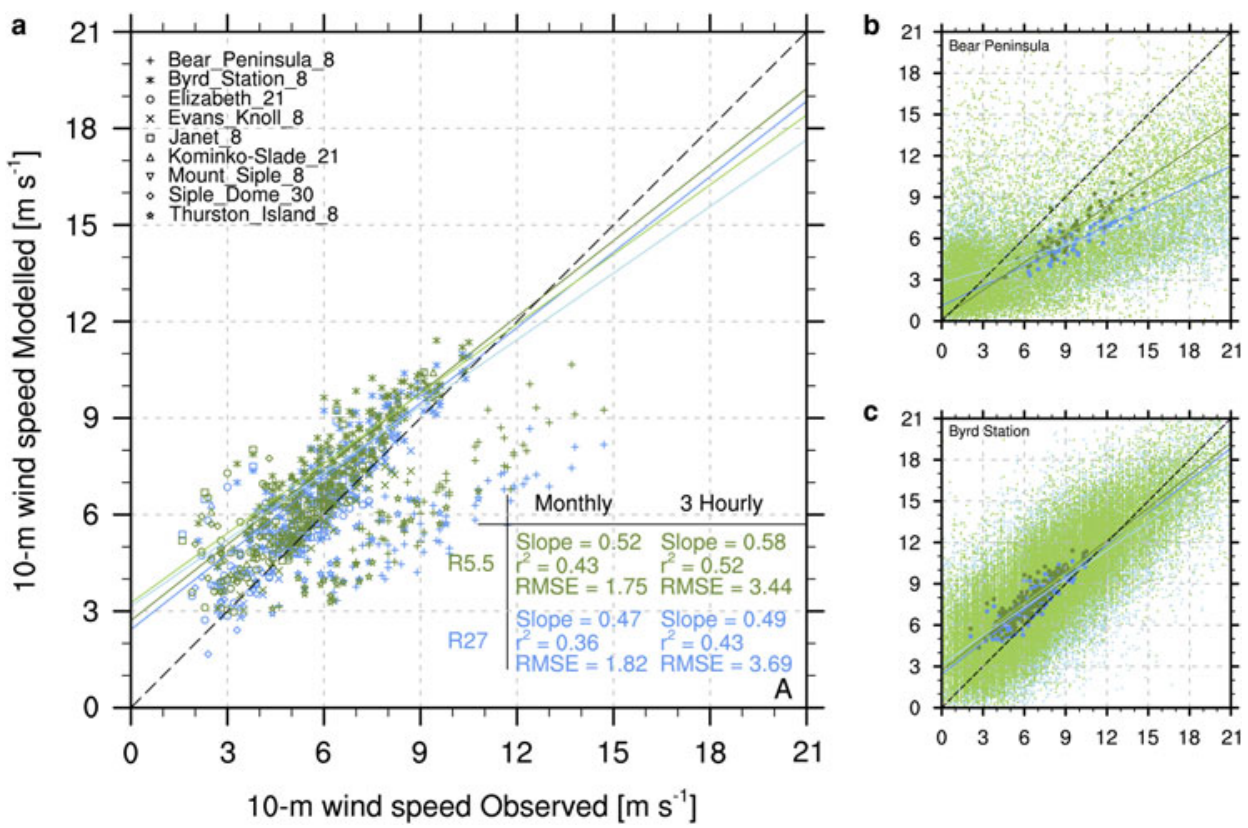

Fig. 4. Scatter plots of observed (AWS) vs. simulated (R5.5 in green, R27 in blue) near-surface wind speed. (a) All stations; (b) Bear Peninsula; (c) Byrd Station. In panels (b) and (c), the opaque markers show the 3-hourly data, and the clear markers show the monthly mean data. The statistics are given for both monthly and 3-hourly comparisons in each plot. The coloured lines show the 1:1 line (black) and the best linear fit for R5.5 (green) and R27 (blue). 
wind speed is underestimated by $\sim 40 \%$ by both model simulations. Again, this difference is likely caused by the position of the AWS on topographical highs resulting in high measured wind speeds. Interestingly enough, this does not apply to Evans Knoll, although the station is also located at the top of an island in a large flat ice shelf.

For the inland stations, the agreement is much better with lower RMSE values and slopes near 1.0 (Table A2). However, a systematic bias is observed with simulated wind speeds slightly higher than those measured. This is especially clear for Byrd Station (Fig. 4c) where the monthly mean RACMO2 values show an overestimation of observed wind speed of $1.0-1.5 \mathrm{~m} \mathrm{~s}^{-1}$, while the slope is virtually 1.0 . As the overestimation is present in both model simulations, a possible cause could be that the roughness length in RACMO2 is slightly too low, yielding too strong nearsurface winds. Other possible explanations are related to the excessive momentum diffusion in RACMO2, and/or the limited vertical resolution (only three vertical layers below $100 \mathrm{~m}$ ), which limits the ability of a regional climate model to represent the boundary layer near the coastal domes.

Noteworthy is the cluster of points at the bottom left of Figure 4a that shows low measured wind speeds in combination with high simulated wind speeds. These respective months are probably affected by rime formation on the wind meter, as some 3-hour data show near-zero wind speed conditions, while RACMO2 simulates $>10 \mathrm{~m} \mathrm{~s}^{-1}$.
Especially the statistics of Janet station (Table A2) might be affected by this as this occurs in $10-15 \%$ of the measured months. We decided not to remove any 3-hourly or monthly data as we had no data to determine whether a measurement was a normal outlier or was the result of instrument malfunctioning by e.g. rime formation.

\section{Surface melt}

With the cold climate characterizing much of WAIS, surface melt does not frequently occur over most of the grounded ice sheet (Fig. 5), and is confined to ice shelves. The highest surface melt rates $\left(>100 \mathrm{~mm}\right.$ w.e. $\left.\mathrm{a}^{-1}\right)$ are found over parts of Abbott ice shelf, Cosgrove ice shelf and eastern Pine Island ice shelf. Note that these melt rates are still a factor of five to ten lower than those observed on the eastern Antarctic Peninsula ice shelves (Trusel and others, 2013). Much lower surface melt rates prevail over the ice shelves in the western half of the domain, and surface melt on Ross Ice Shelf (not shown) only occurs in anomalously warm summers, as driven for example by strong El Niño conditions (Nicolas and others, 2017). Although the absolute surface melt rates are $30-50 \%$ lower, the patterns of RACMO2 surface melt agree very well with the observations. One possible reason for the underestimation of surface melt, apart from the uncertainty associated with the conversion from radar backscatter to surface melt volume in the QSCAT

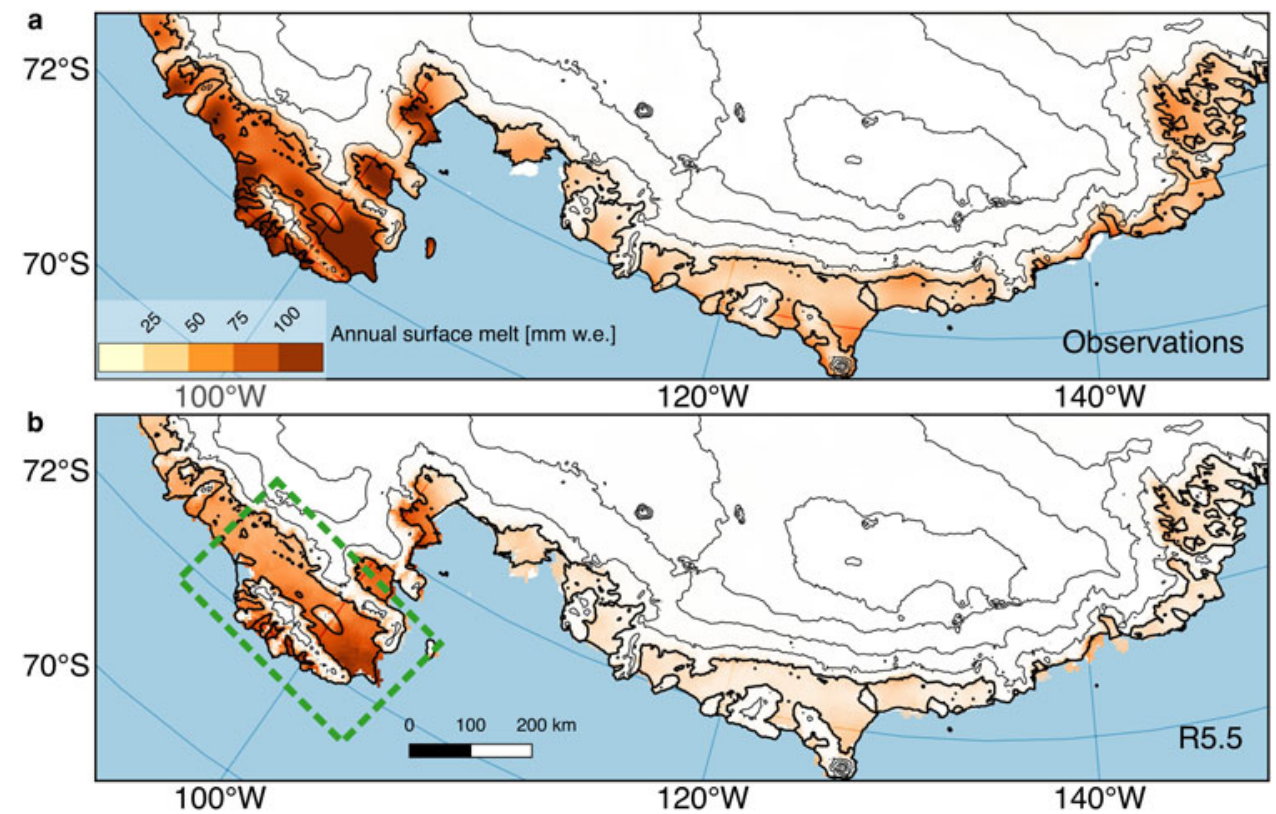

c
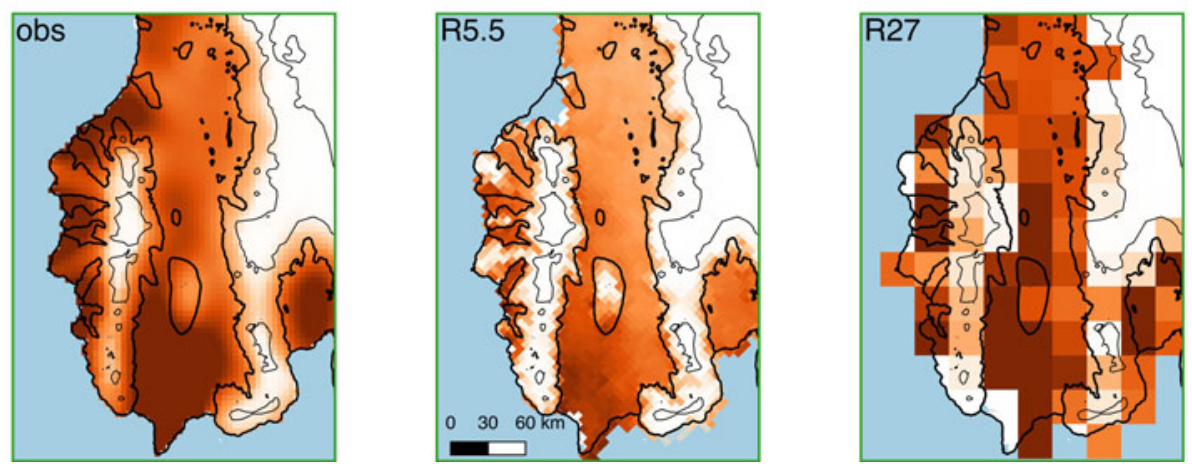

Fig. 5. Annual mean 2000-09 surface melt volume (mm w.e. $\mathrm{a}^{-1}$ ) according to (a) observations derived from QuikScat and (b) R5.5. Panel (c) shows a comparison of observations, R5.5 and R27 on the Abbott ice shelf. 


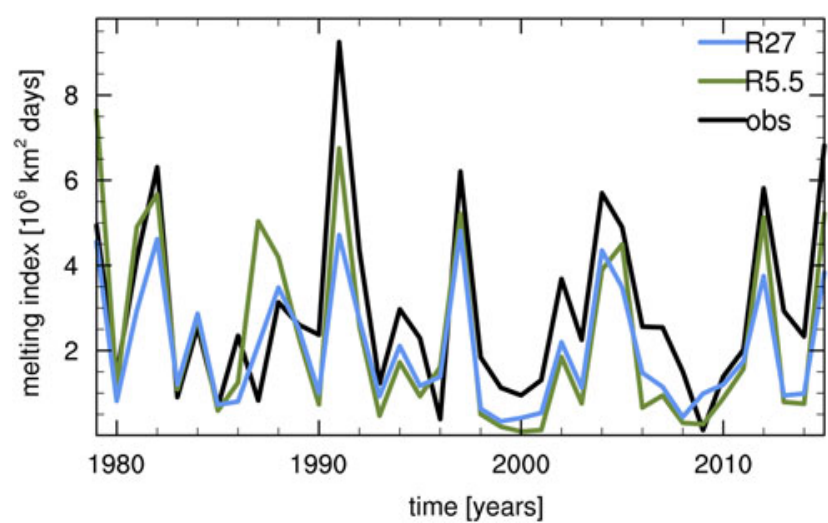

Fig. 6. Time series (1979-2015) of annual melt index for the area between 100 and $160^{\circ} \mathrm{W}$ according to observations (black) and R5.5. To define the occurrence of surface melt in R5.5, we use a daily surface melt threshold of $3 \mathrm{~mm}$ w.e. Note that each year (e.g. 1979) refers to the summer starting in that year (e.g. 1979-80).

observational product, is the positive RACMO2 summer albedo bias (Lenaerts and others, 2017b), which delays the onset of the melt-albedo feedback (Van den Broeke and others, 2010). Another explanation is related to the horizontal resolution of the model: although the R27 model does not resolve the spatial melt gradients over Abbott ice shelf (Fig. 5) that are observed and simulated in R5.5, it shows higher surface melt rates that are more consistent with the observations. This suggests that RACMO2, when employed at higher resolution that better resolves local topography, generates too cold conditions on the ice shelf through overestimating ice-shelf snowfall (mitigating the melt-albedo feedback) and/or reinforcing the temperature inversion by under-representing turbulent mixing.
Interannual variability of area-integrated surface melt occurrence is compared with observations in Figure 6. Because we optimized the surface melt threshold in RACMO2, the model estimates $\left(2.3 \pm 2.110^{6} \mathrm{~km}^{2} \times\right.$ days in R5.5 and $2.0 \pm 1.410^{6} \mathrm{~km}^{2} \times$ days in R27) agree very well with the observations $\left(2.9 \pm 2.110^{6} \mathrm{~km}^{2} \times\right.$ days $)$, with all datasets displaying similarly large interannual variability $\left(R^{2}=0.64\right.$ between $R 5.5$ and the observations, and $R^{2}=$ 0.76 between R27 and the observations). Peak melt years, such as 1991, are well simulated by RACMO2. This signals that the model is able to simulate the atmospheric drivers and atmosphere-snow feedbacks causing variability in melt. Additionally, it shows that the enhanced horizontal resolution in R5.5 does not improve the interannual variability of simulated surface melt. One possible reason is that, unlike R27, R5.5 does not include ERA-Interim upper-air relaxation (Van de Berg and Medley, 2016), which improves temporal variability of SMB in RACMO2.

\section{Surface mass balance}

The simulated SMB field is illustrated by Figure 7a. Very high SMB $\left(>1000 \mathrm{~mm}\right.$ w.e. $\left.\mathrm{a}^{-1}\right)$, dominated by snowfall, is found along many coastal ice sheet slopes, especially those that are aligned orthogonal (i.e. west to east) to the prevalent atmospheric moisture flux direction (i.e. north to south). Coastal areas in the lee of other topography, such as Pine Island glacier $\left(100^{\circ} \mathrm{W}, 7^{\circ} \mathrm{D}\right)$ receive much less precipitation. The Ross Ice Shelf, sheltered from much of the synoptic activity in the Amundsen region, is comparably very dry $\left(<200 \mathrm{~mm}\right.$ w.e. $\left.\mathrm{a}^{-1}\right)$. SMB quickly decreases with elevation on the grounded ice sheet, but the SMB remains higher in the western regions, where ice-sheet surface slopes are negative, than towards the east, where slopes remain positive far

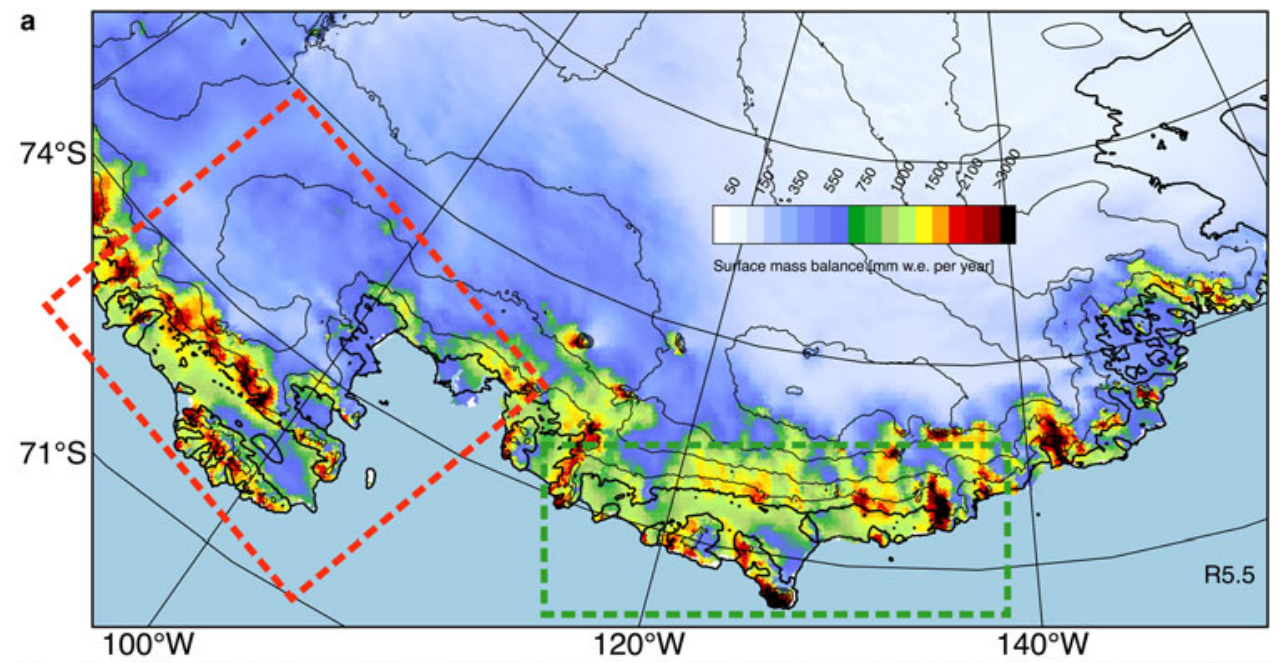

b
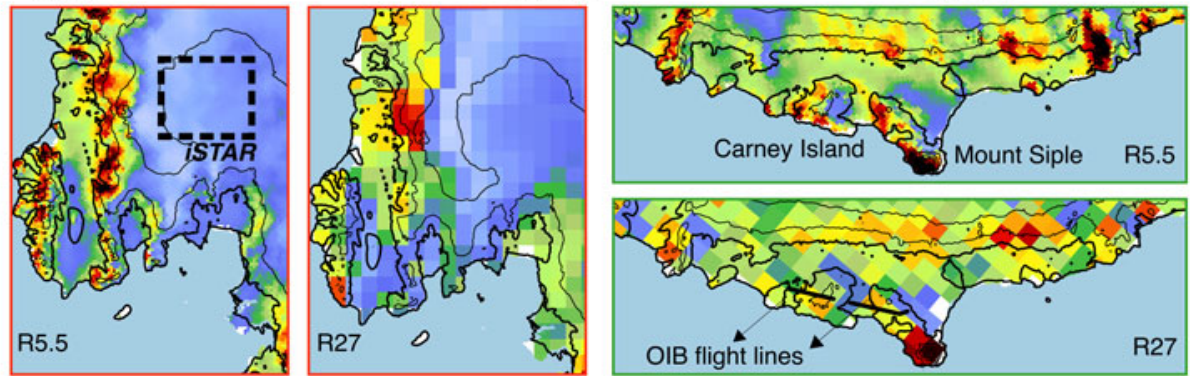

Fig. 7. Annual mean (1979-2015) simulated (R5.5) SMB. (a) Entire domain; (b) Zooms on Abbott ice shelf and Getz ice shelf areas (see red and green squares in (a)), including comparisons with R27. The approximate locations of the iSTAR study area and OIB flight lines are shown in (b). 
inland. This is especially evident over the ASE (east of $120^{\circ} \mathrm{W}$ ), where SMB exceeds $500 \mathrm{~mm}$ w.e. $\mathrm{a}^{-1}$ up to $2000 \mathrm{~m}$ a.s.l.

Over Pine Island and Thwaites glacier catchments, the spatial correspondence of R27 and R5.5 with 1985-2009 mean annual radar-derived SMB (Medley and others, 2013, 2014, not shown) shows a similarly good agreement with observations for both datasets $\left(R^{2}=0.69\right.$ for $\mathrm{R} 5.5, R^{2}=$ 0.67 for $\mathrm{R} 27)$. The dry bias relative to the radar observations (mean $\mathrm{SMB}=409 \mathrm{~mm}$ w.e. $\mathrm{a}^{-1}$ ) is enhanced in R5.5 (mean $=355 \mathrm{~mm}$ w.e. $\mathrm{a}^{-1}$ ) as compared with R27 (mean = 372 $\mathrm{mm}$ w.e. $\mathrm{a}^{-1}$ ), but remains consistent with other atmospheric reanalysis datasets (Medley and others, 2013). To complement this analysis, we use firn core and GPR observations obtained in this area by the iSTAR project (see Fig. 7b). These allow us to perform a comparison of R5.5 and R27 (Fig. 8). Along the iSTAR transect, the observed SMB decreases from $450 \mathrm{~mm}$ w.e. $\mathrm{a}^{-1}$ to $250 \mathrm{~mm}$ w.e. $\mathrm{a}^{-1}$ in the first part of the transect (from sites 5 to a) that runs from southeast to northwest, and increases back to $>500 \mathrm{~mm}$ w.e. $\mathrm{a}^{-1}$ when returning to the west (sites 11 to 13). Although R5.5 and R27 both broadly represent that pattern, R5.5 approaches the observations much better than R27. The mean bias with respect to the observations along the transect is reduced from $84 \mathrm{~mm}$ w.e. $\mathrm{a}^{-1}$ in R27 to $32 \mathrm{~mm}$ w.e. $\mathrm{a}^{-1}$ in R5.5. The RMSE decreases from $110 \mathrm{~mm}$ w.e. $\mathrm{a}^{-1}$ in R27 to 77 mm w.e. $\mathrm{a}^{-1}$ in R5.5. Moreover, R5.5 partly reproduces smaller-scale variations that are present in the observations, such as the strong SMB increase around sites 11 and 12 . This indicates that R5.5 better reproduces the absolute $\mathrm{SMB}$, as well as its gradients, on Pine Island Glacier.

Next, RACMO2 is compared to available PAGES $2 \mathrm{k}$ ice cores (Fig. 9) for the overlapping period. Overall, both R5.5 and R27 compare very well to the available SMB observations, with a relative bias not exceeding $30 \%$ for all firn cores. In contrast to the better performance of R5.5 with respect to the iSTAR results, we find here a slightly better overall performance of R27 (mean bias $=<1 \mathrm{~mm}$ w.e. $\mathrm{a}^{-1}$ ) than of R5.5 (mean bias $=-17 \mathrm{~mm}$ w.e. $\mathrm{a}^{-1}$ ). The SMB underestimation in R5.5 is most strongly manifested at the firn core locations in the eastern part of our domain (around $90^{\circ} \mathrm{W}$, not shown). We speculate that R5.5, at this high horizontal resolution, simulates excessive orographic snowfall on the coastal slopes in this region (Fig. 7), leaving the interior areas with a dry bias.
In the coastal regions, where no firn records are available, the high resolution enables R5.5 to represent the large SMB gradients induced by topography that has finer horizontal scales $(<50 \mathrm{~km})$, and are thus not resolved by global atmospheric reanalyses or coarser-scale models, such as R27. This is evidenced by the much smoother gradients in $\mathrm{R} 27$ relative to R5.5 in the ASE and around the Getz ice shelf (Fig. 7b). We can assess the performance of both models in representing these small-scale gradients through a comparison with the IceBridge derived SMB over two topographic features on the south side of the Getz ice shelf (Carney Island and Siple Mountain, Fig. 7b). On Carney Island (Fig. 10a), whose divide extends $\sim 700 \mathrm{~m}$ above the ice shelf, the observations suggest a twofold increase (from $800(\sim 45 \mathrm{~km}$ from the divide) to $1500 \mathrm{~mm}$ w.e. $\mathrm{a}^{-1}$ ( $15 \mathrm{~km}$ east of the divide)) in SMB from the windward side, after which SMB quickly decreases towards and behind the divide. This pattern is indicative of a strong orographic component in snowfall, peaking on the windward side and quickly decreasing in the downwind direction. Additionally, wind-driven snow erosion around and in the lee of the divide might further act to reduce SMB in these regions (Lenaerts and others, 2014a). As shown by the simulated topography, R5.5 much better captures the elevation of Carney Island. However, it fails to fully reproduce the observed signal, as it shows an SMB increasing up to $\sim 30 \mathrm{~km}$ from the divide, but an SMB decrease further towards the west. Moreover, the orographic enhancement of SMB is underestimated, with SMB increasing from 900 to $1200 \mathrm{~mm}$ w.e. $\mathrm{a}^{-1}$. R27, on the other hand, does not allow a detailed pattern of $\mathrm{SMB}$, but better captures the value of SMB close to the divide. The orographic precipitation enhancement is ever more significant on Siple Mountain, where the observations indicate an SMB rise from $\sim 350 \mathrm{~mm}$ w.e. $\mathrm{a}^{-1}$ to $>1200 \mathrm{~mm}$ w.e. $\mathrm{a}^{-1}$ at $\sim 5 \mathrm{~km}$ east of the divide. R5.5 shows a similar four-fold increase of $\mathrm{SMB}$, but (i) strongly overestimates the absolute $\mathrm{SMB}$ on the entire windward slope, and (ii) displaces the SMB maximum $\sim 15 \mathrm{~km}$ away from the divide. In contrast, R27 simulates SMB values that are overall consistent with the observations, despite poorly representing the topography and spatial SMB patterns. These results indicate that, although R5.5 simulates much more details in the orographic-precipitation induced SMB patterns on coastal
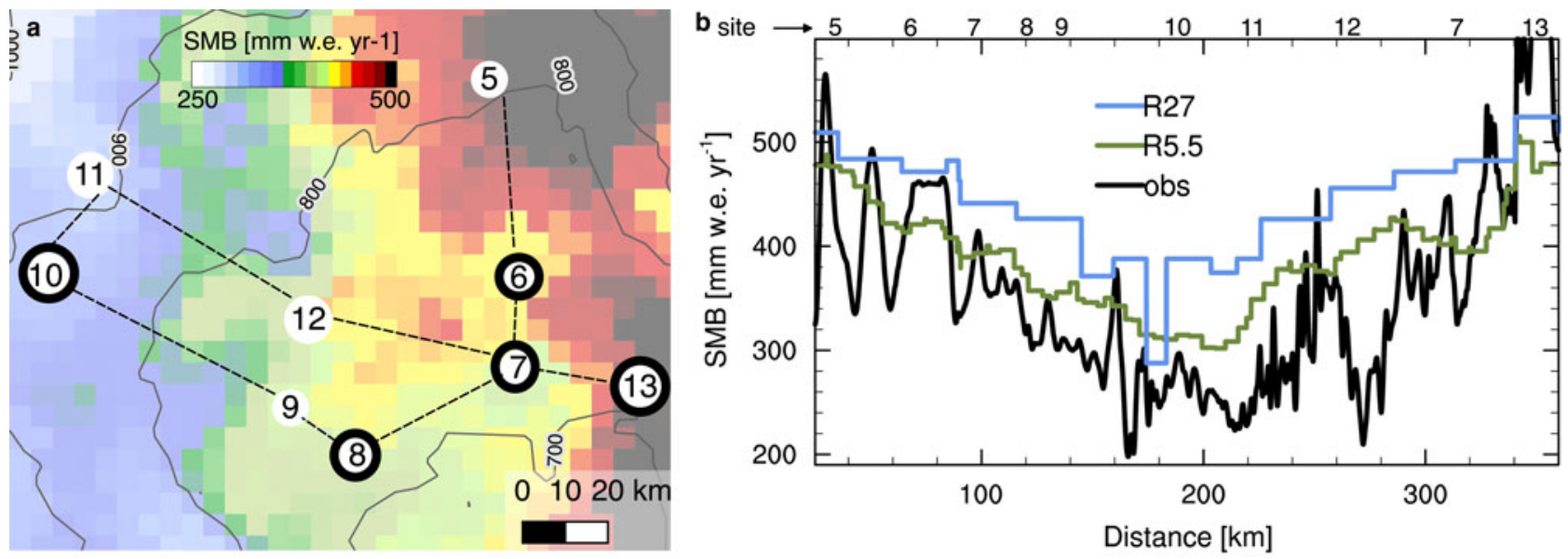

Fig. 8. Comparison of observed and simulated (R5.5 in green, R27 in blue) SMB along iSTAR transect (see Fig. 7b for location). (a) location of firn cores (encircled white dots), other iSTAR landmarks (open white dots), and GPR transect (dashed lines), with R5.5 mean SMB and $100 \mathrm{~m}$ elevation contours in the background; (b) 1980-2014 mean SMB along transect. The location of the sites is shown on the top. 


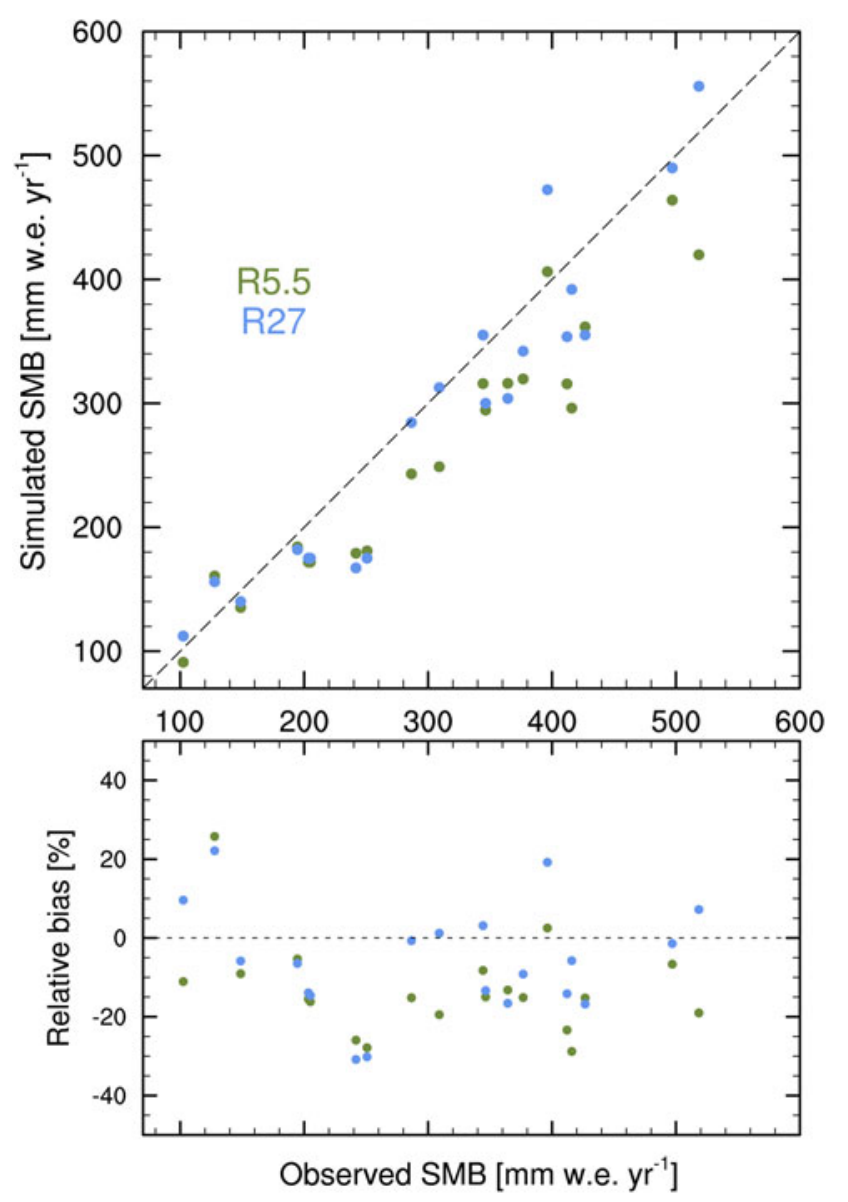

Fig. 9. Scatter plot of observed (firn cores) vs. simulated (R5.5 in green, R27 in blue) annual mean (1979-2012, or the overlapping sub-period) SMB. (a) absolute values; (b) relative bias of the models with respect to the observations.
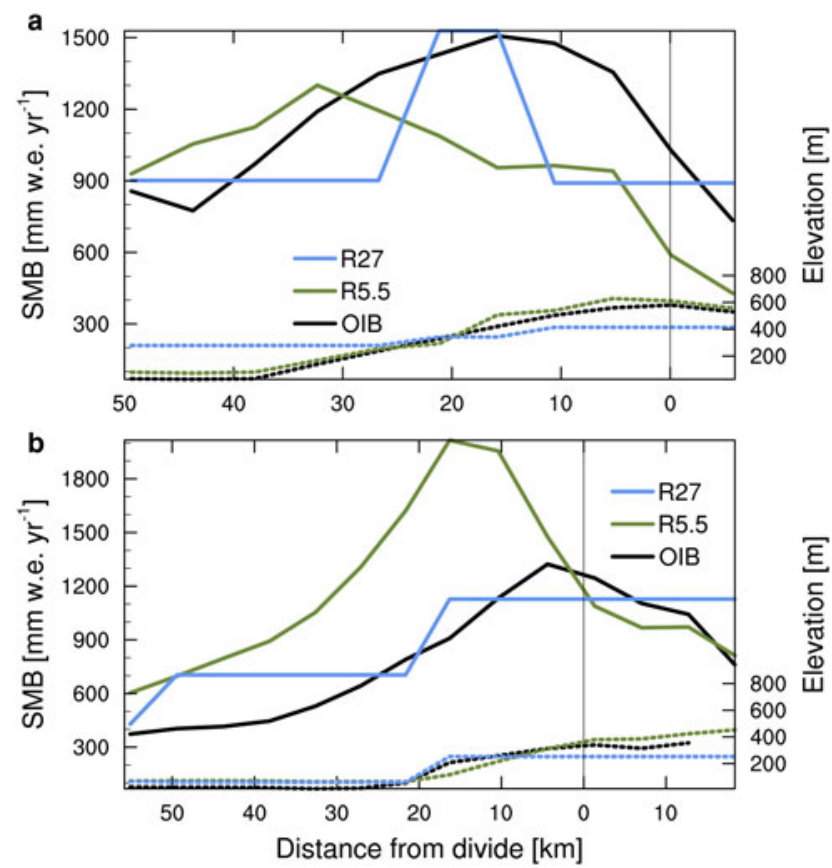

Fig. 10. Horizontal cross-sections running east (left) to west (right) of topography (dashed lines) and annual mean SMB (solid lines, 2012 2014) according to the observations (OIB) and RACMO2 (R5.5 in green, R27 in blue) on Carney Island (top) and Siple Mountain (bottom). The vertical black line denotes the approximate location of the divide. See Figure 7 for the location of the cross-sections.

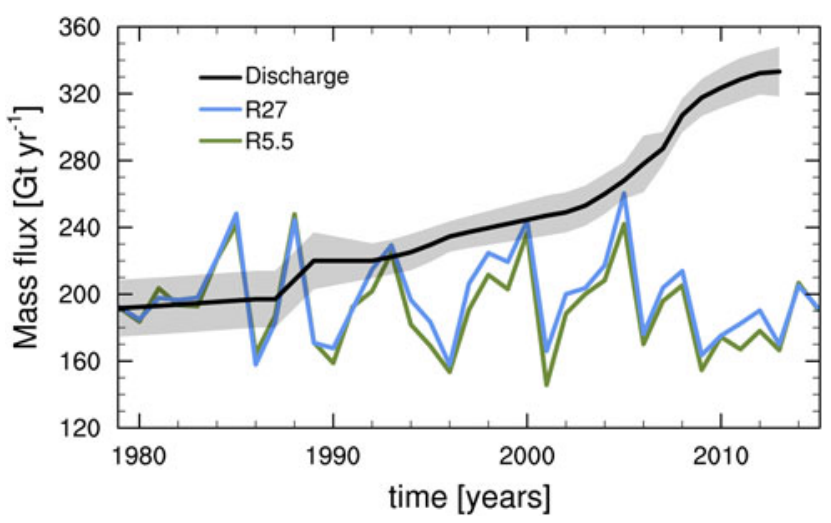

Fig. 11. Simulated (R5.5 in green, $\mathrm{R} 27$ in blue) annual areaintegrated SMB (1979-2015) and ice discharge (1979-2013, taken from Mouginot and others, 2014) of the Amundsen embayment glacier basins (see Fig. 1b for extent).

domes, the resulting absolute SMB values are not necessarily more realistic than in $\mathrm{R} 27$.

Our comparison with detailed observations clearly indicates that R5.5 and R27 simulate different SMB patterns on small spatial scales. In this regard, the question remains whether we need to resolve the climate at $5.5 \mathrm{~km}$ resolution to obtain a realistic area-integrated SMB flux. To answer this question, we integrated the R5.5 and R27 SMB over the whole ASE glacier area. This area, encompassing 428000 $\mathrm{km}^{2}$, includes the Pine Island, Thwaites, Kohler, Smith and Pope glaciers. By differencing the cumulative solid ice flux along the grounding line of these glaciers (Mouginot and others, 2014) with the area integrated SMB (Fig. 11), we can assess the mass balance of this area (Rignot and others, 2011). Up to the late 1980 's, the ice flux and SMB were approximately equal, although strong SMB showed strong inter-annual variations, resulting in negative mass balance in low-SMB years (e.g. 1984 or 1988) and positive mass balance in high-SMB years (e.g. 1986). From then onwards, multi-annual SMB remains constant, while the ice discharge increases steadily from $\sim 200$ to $330 \mathrm{Gta}^{-1}$. This has caused a series of negative mass balance years, with the exception of a few high-SMB years, when SMB and ice discharge cancelled out (1993, 2000, and 2005). Since 2005, the combination of high ice discharge and low SMB has led to strongly negative mass balance in each year $\left(-150\right.$ to $\left.-100 \mathrm{Gta}^{-1}\right)$. If we compare area-integrated SMB from R5.5 and R27, we find very small differences $\left(<20 \mathrm{Gta}^{-1}\right)$, approximately the same order of magnitude as the uncertainty in the ice discharge and the error traditionally assigned to SMB in mass balance studies (Depoorter and others, 2013). This illustrates that RACMO2 applied at higher horizontal resolution does not give conclusive added value for basin-wide mass balance estimates.

\section{DISCUSSION AND CONCLUSIONS}

Here we presented output from a high-resolution $(5.5 \mathrm{~km})$ regional atmospheric climate model (RACMO2) and assessed the performance of this model in comparison with a set of novel, so far partly undocumented observations, and with a version of RACMO2 with lower horizontal resolution $(27 \mathrm{~km})$.

Our analysis shows that the high-resolution model (R5.5) compares very well with observations of near-surface climate, surface melt and SMB. It substantially outperforms 
the low-resolution model (R27) for both 2-m temperature and $10-\mathrm{m}$ wind speed. Especially for coastal stations, the enhanced topographical detail helps to better simulate the temperature and wind climate. Although the absolute values of surface melt are underestimated, the spatial patterns, extent, and interannual variability are very well simulated by R5.5. For SMB, we found a mixed signal, with better performance of R5.5 over the Pine Island Glacier, but an overall negative bias at interior sites. R27, on the other hand, very well represents SMB in comparison with interior firn core records.

In the coastal regions, we find very high simulated SMB on the windward side of topographic features in R5.5, which are partly confirmed by airborne radar observations. However, significant biases are found in the simulated absolute $S M B$ values, as well as the location of the SMB maximum on the windward slope. These results suggest that, employed at this resolution, RACMO2 produces excessive orographic snowfall rates, which, in return, lead to a dry bias in parts of the interior ice sheet. In contrast, R27 does not resolve these smaller topographic features and related snowfall patterns, but generates a coast-interior SMB gradient that appears to be equally, if not more, consistent with observations.

Overall, the high resolution in RACMO2 resolves smallscale climate, surface melt and SMB patterns that are not resolved by lower-resolution models, reanalyses and observational datasets (Medley and others, 2013). This dataset can therefore prove useful to aid in the choice of an ice core location, in understanding regional near-surface climate variability, and in forcing high-resolution ice-sheet and/or ocean models. Moreover, altimetry estimates of ice sheet elevation change resolve the detailed pattern of change; however, an outstanding challenge is how to convert from volume to mass. One approach is to correct the altimetry-derived rate of elevation change for elevation change associated with surface processes (Ligtenberg and others, 2011; Wouters and others, 2015), but any error in either the data or the correction will then be converted to mass change at the density of ice, leading to a bias in the final result (Hogg and others, 2017). In the future, we recommend that the high spatial resolution R5.5 SMB is used as the input for a high-resolution firn compaction model, which may improve the accuracy with which we can partition surface mass and dynamically induced elevation change. However, one should be cautious when using this dataset around small-scale coastal topography, where model biases remain substantial.

Ongoing and future RACMO2 development should focus on reducing the bias of orographic precipitation. In particular, RACMO2 currently does not calculate precipitation prognostically, which implies that snow falls in the same grid cell as it was generated. Employed at horizontal grid sizes smaller than the typical distance between in-cloud snow grain formation and snowfall (10-20 km), this will inevitably lead to biases in the location of SMB maxima in high-precipitation regions, such as coastal domes. Additionally, RACMO2 uses the hydrostatic approximation, which might explain some of the biases found in the high-resolution model. Atmospheric processes at spatial scales similar to the R5.5 grid size that drive high vertical velocities and vigorous mixing, such as strong convection along the steep slopes inward of the iceshelf grounding lines and orographic lifting on windward sides of coastal domes, might be poorly represented. Therefore, future work should also target developing nonhydrostatic models for this application.

\section{DATA AVAILABILITY}

RACMO2 data are available by request to the corresponding author (Jan.Lenaerts@colorado.edu). AWS data are available through the AMRC and Automatic Weather Station (AWS) program. Surface melt datasets are available from L. D. Trusel (trusel@rowan.edu) and J. P. Nicolas (nicolas. $7 @$ osu.edu). The firn core records collated for the Antarctica $2 \mathrm{k}$ project are available at the UK Polar Data centre or by request from E. R. Thomas (lith@bas.ac.uk). Operation IceBridge SMB data are available from Brooke Medley (brooke.c.medley@nasa.gov). The observations of SMB along the iSTAR traverse are available on request from Anna Hogg (A.E.Hogg@leeds.ac.uk).

\section{SUPPLEMENTARY MATERIAL}

The supplementary material for this article can be found at https://doi.org/10.1017/aog.2017.42.

\section{ACKNOWLEDGMENTS}

J. T. M. L. and S. R. M. L. are funded by the Netherlands Science Organization through the Innovational Research Incentives Scheme Veni. H. K., R. M., R. J. T. and A. E. H. were supported by the UK Natural Environment Research Council's iSTAR Programme. The authors appreciate the support of the University of Wisconsin-Madison Automatic Weather Station Program for the data set, data display and information, NSF grant number ANT-1543305, and of the iSTAR management and field logistics. Data analysis and plotting were performed using the the NCAR Command Language (UCAR/NCAR/CISL/NETS, 2014) and the QGIS Quantarctica package developed by the Norwegian Polar Institute.

\section{REFERENCES}

Armstrong R, Knowles K, Brodzik MJ and Hardman MA (1994) DMSP SSM/I-SSMIS Pathfinder Daily EASE-Grid Brightness Temperatures, Version 2, NASA National Snow and Ice Data Center Distributed Active Archive Center. [online] Available from: http://dx.doi.org/10.5067/3EX2U1DV3434 (Accessed 10 March 2017).

Bamber JL, Gomez-Dans JL and Griggs JA (2009) A new 1 km digital elevation model of the Antarctic derived from combined satellite radar and laser data - part 1: data and methods. Cryosphere, 3(1), 101-111 (doi: 10.5194/tc-3-101-2009)

Bertler NAN, Naish TR, Mayewski PA and Barrett PJ (2006) Opposing oceanic and atmospheric ENSO influences on the Ross Sea Region, Antarctica. Adv. Geosci., 6, 83-86 (doi: 10.5194/adgeo-6-83-2006)

Bracegirdle TJ and Marshall GJ (2012) The reliability of antarctic tropospheric pressure and temperature in the latest global reanalyses. J. Clim., 25(20), 7138-7146 (doi: 10.1175/JCLI-D11-00685.1)

Bromwich DH, Monaghan AJ and Guo Z (2004) Modeling the ENSO modulation of Antarctic climate in the late 1990s with the Polar MM5. J. Clim., 17(1), 109-132 (doi: 10.1175/1520-0442(2004) 017;0109:MTEMOA 2 2.0.CO;2)

Clem KR and Renwick JA (2015) Austral spring Southern hemisphere circulation and temperature changes and links to the SPCZ. J. Clim., 28(18), 7371-7384 (doi: 10.1175/JCLI-D-15-0125.1)

Connolley WM (1997) Variability in annual mean circulation in southern high latitudes. Clim. Dyn., 13(10), 745-756 (doi: $10.1007 / \mathrm{s} 003820050195)$ 
DeConto RM and Pollard D (2016) Contribution of Antarctica to past and future sea-level rise. Nature, 531(7596), 591-597 (doi: 10.1038/nature17145)

Dee DP and 35 others (2011) The ERA-Interim reanalysis: Configuration and performance of the data assimilation system. Q. J. R. Meteorol. Soc., 137(656), 553-597 (doi: 10.1002/qj.828)

Depoorter MA and 6 others (2013) Calving fluxes and basal melt rates of Antarctic ice shelves.. Nature, 502(7469), 89-92 (doi: 10.1038/nature12567)

Déry SJ and Yau MK (1999) A bulk blowing snow model. Bound.Layer Meteorol., 93(2), 237-251

Ding Q, Steig EJ, Battisti DS and Kuttel M (2011) Winter warming in West Antarctica caused by central tropical Pacific warming. Nat. Geosci, 4(6), 398-403

Doyle JD and Shapiro MA (1999) Flow response to large-scale topography: the Greenland tip jet. Tellus A Dyn. Meteorol. Oceanogr., 51(5), 728-748 (doi: 10.3402/tellusa.v51i5.14471)

ECMWF-IFS (2008) Part IV: physical processes (CY33R1). Technical Report. European Centre for Medium-Range Weather Forecasts (ECMWF)

Ettema J, van den Broeke MR, van Meijgaard E and van de Berg WJ (2010) Climate of the Greenland ice sheet using a high-resolution climate model - Part 1: Evaluation. Cryosphere, 4(2), 511-527. (doi: 10.5194/tc-4-511-2010)

Fretwell P and 59 others (2013) Bedmap2: improved ice bed, surface and thickness datasets for Antarctica. Cryosphere, 7(1), 375-393. (doi: 10.5194/tc-7-375-2013)

Fyke J, Lenaerts J and Wang $\mathrm{H}$ (2017) Countervailing regional snowfall patterns dampen Antarctic mass variability. Cryosph. Discuss., 1-24 (doi: 10.5194/tc-2017-102)

Gorodetskaya IV and 5 others (2014) The role of atmospheric rivers in anomalous snow accumulation in East Antarctica. Geophys. Res. Lett., 41(17), 6199-6206 (doi: 10.1002/2014GL060881)

Hogg AE and 11 others (2017) Increased ice flow in Western Palmer Land linked to ocean melting. Geophys. Res. Lett., 44(9), 41594167 (doi: 10.1002/2016GL072110)

Hubbard B and 12 others (2016) Massive subsurface ice formed by refreezing of ice-shelf melt ponds. Nat. Commun., 7, 11897 (doi: 10.1038/ncomms11897)

Jacobs SS and 6 others (2012) The Amundsen Sea and the Antarctic ice sheet. Ocenaography, 25(3), 154-163 (doi: 10.5670/ oceanog.2012.90)

Jones RW and 5 others (2016) Evaluation of four global reanalysis products using in situ observations in the Amundsen Sea Embayment, Antarctica. J. Geophys. Res. Atmos., 121(11), 6240-6257 (doi: 10.1002/2015JD024680)

Joughin I, Smith BE and Medley B (2014) Marine ice sheet collapse potentially under way for the Thwaites Glacier Basin, West Antarctica. Science, 344(6185), 735-738

King JC (1998) Using satellite thermal infrared imagery to study boundary layer structure in an Antarctic katabatic wind region. Int. J. Remote Sens., 19(17), 3335-3348 (doi: 10.1080/ 014311698214028)

Knowles K, Njoku EG, Armstrong R and Brodzik MJ (2000) Nimbus-7 SMMR Pathfinder Daily EASE-Grid Brightness Temperatures, Version 1, NASA National Snow and Ice Data Center Distributed Active Archive Center, Boulder, Colorado, USA. [online] Available from: http://dx.doi.org/10.5067/36SLCSCZU7N6 (Accessed 10 March 2017).

Konrad $\mathrm{H}$ and 6 others (2017) Uneven onset and pace of ice-dynamical imbalance in the Amundsen Sea Embayment, West Antarctica. Geophys. Res. Lett., 44(2), 910-918 (doi: 10.1002/2016GL070733)

Kovacs A, Gow AJ and Morey RM (1995) The in-situ dielectric constant of polar firn revisited. Cold Reg. Sci. Technol., 23(3), 245256 (doi: 10.1016/0165-232X(94)00016-Q)

Krabill WB (2010) IceBridge ATM L2 Icessn Elevation, Slope, and Roughness. Version 2 (doi: 10.5067/CPRXXK3F39RV)

Kuipers Munneke P and 5 others (2011) A new albedo parameterization for use in climate models over the Antarctic ice sheet? J. Geophys. Res. Atmos., 116(5) (doi: 10.1029/2010JD015113)
Kuipers Munneke P, Van Den Broeke MR, King JC, Gray T and Reijmer CH (2012) Near-surface climate and surface energy budget of Larsen C ice shelf, Antarctic Peninsula? Cryosphere, 6(2), 353-363 (doi: 10.5194/tc-6-353-2012)

Kuipers Munneke P, Ligtenberg SRM, Van Den Broeke MR and Vaughan DG (2014) Firn air depletion as a precursor of Antarctic ice-shelf collapse? J. Glaciol., 60(220), 205-214 (doi: 10.3189/2014JoG13J183)

Lenaerts JT, Van Tricht K, Lhermitte S and L'Ecuyer TS (2017a) Polar clouds and radiation in satellite observations, reanalyses, and climate models. Geophys. Res. Lett., 44(7) (doi: 10.1002/ 2016GL072242)

Lenaerts JTM and Van Den Broeke MR (2012) Modeling drifting snow in Antarctica with a regional climate model: 2. Results. J. Geophys. Res. Atmos., 117(5) (doi: 10.1029/2010JD015419)

Lenaerts JTM, van den Broeke MR, van Angelen JH, van Meijgaard E and Déry SJ (2012a) Drifting snow climate of the Greenland ice sheet: a study with a regional climate model. Cryosphere, 6(4), 891-899 (doi: 10.5194/tc-6-891-2012)

Lenaerts JTM, van den Broeke MR, van de Berg WJ, Van Meijgaard E and Kuipers Munneke P (2012b) A new, high-resolution surface mass balance map of Antarctica (1979-2010) based on regional atmospheric climate modeling. Geophys. Res. Lett., 39(L04501) (doi: 10.1029/2011GL050713)

Lenaerts JTM and 11 others (2014a) High variability of climate and surface mass balance induced by Antarctic ice rises. J. Glaciol., 60 (224), 1101-1110 (doi: 10.3189/2014JoG14J040)

Lenaerts JTM and 6 others (2014b) Drifting snow measurements on the Greenland Ice Sheet and their application for model evaluation. Cryosphere, 8(2), 801-814, ISSN 19940424 (doi: 10.5194/tc-8-801-2014)

Lenaerts JTM and 12 others (2017b) Meltwater produced by windalbedo interaction stored in an East Antarctic ice shelf. Nat. Clim. Chang., 7(1), 58-62

Leuschen C (2014) updated 2017. IceBridge Snow Radar L1B Geolocated Radar Echo Strength Profiles, Version 2. Boulder, Colorado USA. NASA National Snow and Ice Data Center Distributed Active Archive Center. doi: 10.5067/FAZTWP500V70.

Ligtenberg SRM, Helsen MM and van den Broeke MR (2011) An improved semi-empirical model for the densification of Antarctic firn. Cryosphere, 5(4), 809-819. (doi: 10.5194/tc-5-809-2011)

Liu H, Wang L and Jezek KC (2006) Spatiotemporal variations of snowmelt in Antarctica derived from satellite scanning multichannel microwave radiometer and Special Sensor Microwave Imager data (1978-2004). J. Geophys. Res., 111(F1), F01003 (doi: 10.1029/2005JF000318)

Luckman A and 6 others (2014) Surface melt and ponding on Larsen C Ice Shelf and the impact of föhn winds. Antarct. Sci., 26(Special Issue 06), 625-635 (doi: 10.1017/ S0954102014000339)

Medley B and 12 others (2013) Airborne-radar and ice-core observations of annual snow accumulation over Thwaites Glacier, West Antarctica confirm the spatiotemporal variability of global and regional atmospheric models. Geophys. Res. Lett., 40(14), 3649-3654 (doi: 10.1002/grl.50706)

Medley B and 14 others (2014) Constraining the recent mass balance of pine island and thwaites glaciers, west antarctica, with airborne observations of snow accumulation. Cryosphere, 8(4) (doi: 10.5194/tc-8-1375-2014)

Medley B and 5 others (2015) Antarctic firn compaction rates from repeat-track airborne radar data: I. Methods. Ann. Glaciol., 56 (70), 155-166 (doi: 10.3189/2015AoG70A203)

Moore GWK and Renfrew IA (2005) Tip jets and barrier winds: a QuikSCAT climatology of high wind speed events around Greenland. J. Clim., 18(18), 3713-3725 (doi: 10.1175/ JCLI3455.1)

Mouginot J, Rignot E and Scheuchl B (2014) Sustained increase in ice discharge from the Amundsen Sea Embayment, West Antarctica, from 1973 to 2013. Geophys. Res. Lett., 41(5), 1576-1584 (doi: 10.1002/2013GL059069) 
Navarro FJ and Eisen O (2009) Ground-penetrating radar. In Pellikka P and Rees WG eds. Remote sens. glaciers. Taylor \& Francis, London, p. 927

Nicolas J and Bromwich D (2011) Precipitation changes in high Southern latitudes from global reanalyses: a cautionary tale. Surv. Geophys., 32(4), 475-494

Nicolas JP and 13 others (2017) January 2016 extensive summer melt in West Antarctica favoured by strong El Niño. Nat. Commun., 8, 15799

Noël B and 5 others (2015) Evaluation of the updated regional climate model RACMO2.3: summer snowfall impact on the Greenland ice sheet. Cryosphere, 9(5), 1831-1844 (doi: 10.5194/tc-9-1831-2015)

Noël B and 11 others (2017) Modelling the climate and surface mass balance of polar ice sheets using RACMO2, part 1: Greenland (1958-2016). Cryosph. Discuss., 1-35 (doi: 10.5194/tc-2017201)

Palerme C and 5 others (2016) Evaluation of current and projected Antarctic precipitation in CMIP5 models. Clim. Dyn., 48(1-2), 225-239, ISSN 14320894 (doi: 10.1007/s00382-016-3071-1)

Panzer B and 8 others (2013) An ultra-wideband, microwave radar for measuring snow thickness on sea ice and mapping nearsurface internal layers in polar firn. J. Glaciol., 59(214), 244 254 (doi: 10.3189/2013JoG12J128)

Paolo FS, Fricker HA and Padman L (2015) Volume loss from Antarctic ice shelves is accelerating. Science, 348(6232), 327 332 (doi: 10.1126/science.aaa0940)

Park JW and 5 others (2013) Sustained retreat of the Pine Island Glacier. Geophys. Res. Lett., 40(10), 2137-2142 (doi: 10.1002/ grl.50379)

Picard G, Fily M and Gallee H (2007) Surface melting derived from microwave radiometers: a climatic indicator in Antarctica. Ann. Glaciol., 46(1), 29-34 (doi: 10.3189/172756407782871684)

Pritchard $\mathrm{H}$ and 5 others (2012) Antarctic ice-sheet loss driven by basal melting of ice shelves. Nature, 484(7395), 502-505 (doi: 10.1038/nature10968)

Raphael MN and 8 others (2015) The Amundsen Sea Low: Variability, Change, and Impact on Antarctic Climate. Bull. Am. Meteorol. Soc., 97(1), 111-121 (doi: 10.1175/BAMS-D-14-00018.1)

Rignot E, Velicogna I, Van Den Broeke MR, Monaghan A and Lenaerts J (2011) Acceleration of the contribution of the Greenland and Antarctic ice sheets to sea level rise. Geophys. Res. Lett., 38(5) (doi: 10.1029/2011GL046583)

Scambos TA and 22 others (2017) How much, how fast?: a science review and outlook for research on the instability of Antarctica's Thwaites Glacier in the 21 st century. Glob. Planet. Change, 153, 16-34 (doi: 10.1016/j.gloplacha.2017.04.008)

Scheuchl B, Mouginot J, Rignot E, Morlighem M and Khazendar A (2016) Grounding line retreat of Pope, Smith, and Kohler Glaciers, West Antarctica, measured with Sentinel-1a radar interferometry data. Geophys. Res. Lett., 43(16), 8572-8579 (doi: 10.1002/2016GL069287)

Seefeldt MW and Cassano JJ (2008) An analysis of low-level jets in the greater Ross ice shelf region based on numerical simulations. Mon. Weather Rev., 136(11), 4188-4205 (doi: 10.1175/ 2008MWR2455.1)

Sigg A and Neftel A (1988) Seasonal variations in hydrogen peroxide in polar ice cores. Ann. Glaciol., 10, 157-162 (doi: 10.1017) S0260305500004353)

Steig EJ, Ding Q, Battisti DS and Jenkins A (2012) Tropical forcing of circumpolar deep water inflow and outlet glacier thinning in the Amundsen Sea Embayment, West Antarctica. Ann. Glaciol., 53 (60), 19-28 (doi: 10.3189/2012AoG60A110)

Tedesco M (2009) Assessment and development of snowmelt retrieval algorithms over Antarctica from K-band spaceborne brightness temperature (1979-2008). Remote Sens. Environ., 113(5), 979997 (doi: 10.1016/j.rse.2009.01.009)

Tedesco M and Monaghan AJ (2009) An updated Antarctic melt record through 2009 and its linkages to high-latitude and tropical climate variability. Geophys. Res. Lett., 36(18) (doi: 10.1029/ 2009GL039186)

Thoma M, Jenkins A, Holland D and Jacobs S (2008) Modelling circumpolar deep water intrusions on the Amundsen Sea continental shelf, Antarctica. Geophys. Res. Lett., 35(18), L18602 (doi: 10.1029/2008GL034939)

Thomas ER and 15 others (2017) Review of regional Antarctic snow accumulation over the past 1000 years. Clim. Past Discuss., 1-42 (doi: 10.5194/cp-2017-18)

Thomas RH (1979) The dynamics of marine ice sheets. J. Glaciol., 24(90), 167-177 (doi: 10.1017/S0022143000014726)

Torinesi O, Fily M and Genthon C (2003) Variability and trends of the summer melt period of Antarctic ice margins since 1980 from microwave sensors. J. Clim., 16(7), 1047-1060

Trusel LD, Frey KE and Das SB (2012) Antarctic surface melting dynamics: Enhanced perspectives from radar scatterometer data. J. Geophys. Res. Earth Surf., 117(2), 1-15 (doi: 10.1029/ 2011JF002126)

Trusel LD, Frey KE, Das SB, Munneke PK, Van Den Broeke MR (2013) Satellite-based estimates of Antarctic surface meltwater fluxes. Geophys. Res. Lett., 40(23), 6148-6153 (doi: 10.1002/ 2013GL058138)

Turner J and 6 others (2017) Atmosphere-ocean-ice interactions in the Amundsen Sea Embayment, West Antarctica. Rev. Geophys., 55 (1), 235-276 (doi: 10.1002/2016RG000532)

UCAR/NCAR/CISL/VETS (2014) The NCAR Command Language (Version 6.2.1 [Software] (doi: 10.5065/D6WD3XH5)

Unden P and 26 others (2002) HIRLAM-5 Scientific documentation. Technical Report 1. Swed. Meteorol. and Hydrol. Inst., Norrköping, Sweden (doi: 10.1007/s00254-002-0712-y)

Van de Berg WJ and Medley B (2016) Brief communication: upper-air relaxation in RACMO2 significantly improves modelled interannual surface mass balance variability in Antarctica. The Cryosphere., 10, 459-463 (doi: 10.5194/tc-10459-2016)

Van den Broeke MR, König-Langlo G, Picard G, Kuipers Munneke P and Lenaerts JTM (2010) Surface energy balance, melt and sublimation at Neumayer Station, East Antarctica? Antarct. Sci., 22 (01), 87 (doi: 10.1017/S0954102009990538)

Van Wessem J and 13 others (2014a) Improved representation of East Antarctic surface mass balance in a regional atmospheric climate model? J. Glaciol., 60(222) (doi: 10.3189/2014JoG14J051)

Van Wessem JM and 5 others (2014b) Updated cloud physics in a regional atmospheric climate model improves the modelled surface energy balance of Antarctica? Cryosphere, 8(1), 125135, ISSN 19940416 (doi: 10.5194/tc-8-125-2014)

Van Wessem JM and 10 others (2016) The modelled surface mass balance of the Antarctic Peninsula at $5.5 \mathrm{~km}$ horizontal resolution? Cryosphere, 10(1), 271-285 (doi: 10.5194/tc-10-271-2016)

Van Wessem JM and 17 others (2017) Modelling the climate and surface mass balance of polar ice sheets using RACMO2, part 2: Antarctica (1979-2016). Cryosph. Discuss., 1-35 (doi: 10.5194/tc-2017-202)

Vaughan DG, Corr HFJ, Doake CSM and Waddington ED (1999) Distortion of isochronous layers in ice revealed by groundpenetrating radar. Nature, 398(6725), 323-326

Wouters B and 7 others (2015) Dynamic thinning of glaciers on the Southern Antarctic Peninsula. Science, 348(6237), 899-903 (doi: 10.1126/science.aaa5727)

Zwally HJ and Fiegles S (1994) Extent and duration of Antarctic surface melting. J. Glaciol., 40(136), 463-476 